\title{
Ensretningen af Flensburger Nachrichten
}

Et blad af Det tredie Riges pressehistorie

\section{Af Carsten R. Mogensen}

I 1983 er der gået 50 år siden nazisternes magtovertagelse i Tyskland. Ensretningen af det tyske samfund satte straks ind i 1933, og pressen gik naturligvis ikke ram forbi. Artiklen illustrerer både et stykke Flensborghistorie og mere generelt den vidtdrevne centralisme, den nazistiske stat baserede sig på, også på presseområdet.

Om sit syn på pressen og dens betydning noterede Hitler i Mein Kampf, at der efter hans opfattelse fandtes tre slags avislæsere: de, der tror på alt, hvad de læser; de, der ikke tror på nogetsomhelst, og de, som foretager en kritisk prøvelse af det læste og tager stilling på grundlag heraf. ${ }^{1} \mathrm{Da}$ langt hovedparten af den tyske befolkning efter Hitlers mening hørte hjemme $\mathrm{i}$ den første gruppe, måtte en af de vigtigste opgaver efter hans udnævnelse til rigskansler og dannelsen af den såkaldte "nationale regering" være at bringe pressen under regimets kontrol. Alle statens magtmidler sattes i foråret 1933 ind på at nå dette mål. Det vigtigste juridiske instrument til opnåelse heraf var den såkaldte Schubladenverordnung, rigspræsidentens forordning "zum Schutze des deutschen Volkes«, som trådte i kraft pr. 4. februar 1933. Denne såkaldte nødforordning gav myndighederne rige muligheder for at undertrykke enhver form for uønsket nyhedsformidling. I dagene op til rigsdagsvalget den 5 . marts svirrede luften med forbud mod aviser, først og fremmest kommunistiske og socialdemokratiske, men også genstridige borgerlige blade kom i klemme i den nazistiske "presse . $^{2}$

Efter nazisternes valgsejr oprettedes under Goebbels' ledelse Reichsministerium für Volksaufklärung und Propaganda, populært kaldet propagandaministeriet eller blot promi, der bl.a. havde til opgave at fuldføre ensretningen af den tyske medieverden med henblik på at sikre myndighedernes kontrol med al nyhedsformidling. Også den slesvigholstenske presse mærkede virkningerne af de nazistiske indgreb mod pressen i foråret 1933, selv om der ikke umiddelbart skete de store ændringer i pressefloraen her. Lokale kommunistiske blade fandtes 
ikke, og det socialdemokratiske Schleswig-Holsteinische Volkszeitung lukkede efter længere tids forbud den 1. april 1933. Forsøg på at redde udgivervirksomhed og trykkeri ved at udgive et nyt partipolitisk "neutralt" og nazivenligt blad mislykkedes. I stedet forvandlede NSDAP i Kiel sit hidtidige ugeblad Der Volkskampf til dagbladet Nordische Rundschau. ${ }^{3}$

Den borgerlige presse havde dels hilst magtovertagelsen med begejstring, dels hurtigt tilpasset sig de ny vilkår. Spørgsmålet var imidlertid, hvor vidt denne tilpasning skulle gå, og om tilpasning overhovedet ville være nok for de ny magthavere. Dette spørgsmål kunne synes besvaret for $i$ hvert fald et borgerligt-nationalt slesvig-holstensk blads vedkommende - Flensburger Nachrichtens - da såvel den redaktionelle som den forretningsmæssige ledelse i Flensburger Nachrichten/Deutscher Verlag GmbH den 11. juli 1933 blev udskiftet med partitro nazister, ligesom tilsynsrådet fik en helt ny sammensætning. Nord for grænsen registrerede man med rette det passerede som udtryk for, at også Flensburger Nachrichten nu var blevet ensrettet, således som man før eller siden måtte vente, det ville ske. ${ }^{4}$

Nogen påfaldende ændring $\mathrm{i}$ bladets redaktionelle linie medførte disse begivenheder ikke. Flensburger Nachrichten - populært kaldet "tante Maass « efter sin første forlægger - havde 1920'erne igennem ligget på en markant tysk-national linie. I januar 1933 havde det hilst Hitlers regeringsdannelse velkommen og lovet den ny regering sin fulde støtte, og op til valgene den 5. og 12. marts havde man kraftigt støttet nazisternes tysk-nationale samarbejdspartner. Nogen form for kritik af Hitlerregeringen eller nazismen havde bladet ikke dristet sig til. Ikke med et ord havde det protesteret mod forbudene mod de politiske partier, herunder til slut også Det tysk-nationale Folkeparti, DNVP, eller mod nazificeringen af hele det tyske samfund, som bl.a. i Flensborg havde ført til det pikante resultat, at det danske mindretal var den eneste ikke-nazistiske gruppering, der var repræsenteret $i$ bystyret. Var der nogen grund til undren over den nazistiske handlemåde, skulle det være over, at man havde fundet det nødvendigt også formelt at ensrette et blad, som så beredvilligt havde gjort »Det ny Tysklands« sag til sin.

Spørgsmålet hvorfor, er imidlertid knap så interessant. At nazisterne ønskede så nøje kontrol med pressen som muligt, er der intet nyt i. Mere spændende er i dette tilfælde spørgsmålet, hvordan. En undersøgelse af dette aspekt synes at rumme perspektiver, som rækker videre end denne enkeltstående begivenhed, der ellers synes så trivielt i 
overensstemmelse med, hvad der i øvrigt skete i Tyskland på dette tidspunkt. På grundlag af hidtil uudnyttet - men desværre også temmelig mangelfuldt - materiale, først og fremmest fra det slesvigholstenske overpræsidiums og Flensborg bys arkiver, har det været muligt i hovedtræk at rekonstruere det hændelsesforløb, som gik forud for Flensburger Nachrichtens endelige overgang på nazistiske hænder, og at forklare, hvorfor ensretningsprocessen i dette tilfælde antog den givne form, også selv om det ikke har været muligt at følge hele udviklingen i detailler. Forinden vil det dog være hensigtsmæssigt først at redegøre skitsemæssigt for Flensburger Nachrichtens historie, da denne er en afgørende kilde til forståelse af begivenhederne i 1933.

\section{Flensburger Nachrichten 1864-1933}

Efter det danske nederlag i krigen 1864 blev det dansksindede, men tysksprogede blad Flensburger Zeitung - dengang Flensborgs eneste annonce- og nyhedsblad - solgt til en holstensk bogtrykker, Ludolph Maass fra Itzehoe, hvorefter det udkom under navnet Flensburger Nachrichten. Bladet var herefter tabt for den danske sag, selv om det $\mathrm{i}$ en årrække i nationalpolitisk henseende forholdt sig temmelig neutralt, formodentlig for at holde på de hidtidige læsere. Bladet fandt senere en vidtgående støtte hos de preussiske myndigheder og fik efterhånden stor udbredelse. Omend det indtil århundredskiftet endnu var mindre end Flensborg Avis, var Flensburger Nachrichten det betydeligste tyske presseorgan i Sønderjylland. ${ }^{5}$

Blandt de tyske blade bevarede Flensburger Nachrichten, som stadig var i familien Maass' eje, også efter afstemningskampen og Nordslesvigs afståelse til Danmark i 1920 sin førende stilling. Det blev dog hurtigt klart, at den ny situation, som skærpedes af efterkrigstidens inflation, krævede en omstrukturering af det tyske pressebillede i grænselandet. Blad efter blad kom i alvorlige økonomiske vanskeligheder og så sig tvunget til dels at undersøge mulighederne for fusion med andre aviser, dels at søge støtte fra tyske grænselandsorganisationer eller offentlige myndigheder. Konkurrencen på avisområdet var særdeles hård $\mathrm{i}$ Flensborg, hvor op til syv-otte lokale blade kæmpede om læsernes gunst. Gennem hele 1921-1922 førtes en række forhandlinger om fusion mellem forskellige tyske aviser i grænseområdet, omend med beskedne resultater. Schleswigsche Grenzpost, der indtil 1920 var udkommet i Haderslev og her havde været talerør for den mest yderligtgående tvangspolitik over for de dansksindede, flyttede efter 
Nordslesvigs afståelse til Flensborg, hvor det fusionerede med Flensburger Tageblatt. Efter kort tid var holdertallet imidlertid skrumpet stærkt ind og ny fusionsforhandlinger, denne gang med Flensburger Nachrichten, som hidtil ikke havde vist tilbøjelighed hertil, blev nødvendige. ${ }^{6}$

I begyndelsen af juli 1922 henvendte Flensburger Nachrichtens forretningsfører og medejer Ernst Maass, der havde strittet imod så længe som muligt, sig til chefredaktør Ernst Schröder fra Schleswigsche Grenzpost. Schröder ledede desuden som repræsentant for den tyske nationale organisation Deutscher Schutzbund dennes såkaldte Grenzmittelstelle Nord i Flensborg. Maass bad ham undersøge mulighederne for en fusion mellem de to blade og for økonomisk støtte fra anden side. Schröder satte sig i forbindelse med Albert Wacker, en flensborgsk avismand, der var medlem af Schutzbunds ledelse, og bad denne kontakte dr. Rathenau i det preussiske indenrigsministerium, eftersom denne var manden, der ville kunne skaffe de midler, som ville være nødvendige. ${ }^{7}$ Den 16 . august 1922 henvendte Wacker sig til det preussiske indenrigsministerium, og efter omfattende og komplicerede forhandlinger - som der her ikke skal gås nærmere ind på - besluttede man at overlade planlægningen af redningsaktionen til en vis Max Winkler, leder af Konkordia Literarische Gesellschaft, der i forvejen var involveret i Schleswigsche Grenzpost. ${ }^{8}$

Konkordia, der var blevet oprettet i januar 1920 og i oktober 1921 overtog den opgave at formidle tysk statsstøtte til den tyske presse i de afståede eller nationalt truede områder, var uden tvivl en af de vigtigste faktorer i støttearbejdet for grænse- og udlandstyskheden i Weimarrepublikken. Konkordias virksomhed var fundamentalt af hemmelig karakter og blev hverken kontrolleret af Rigets eller Preussens myndigheder, men kun af et parlamentarisk tilsynsråd. Konkordias aktioner blev financieret af Riget og Preussen på 50-50 basis, og kun i regnskabsmæssig henseende var selskabet ansvarligt over for Reichsrechnungshof. Takket være inflationen lykkedes det Winkler på Konkordias vegne i begyndelsen af 1920'erne at erhverve en lang række aviser, og når han efter krigen hævdede, at han fra Riga til Konstantinopel havde kontrolleret overhovedet alt, hvad der blev trykt på tysk uden for Tyskland, var det kun en delvis overdrevet påstand. Sålænge de af Winkler kontrollerede aviser, forlag og trykkerier var pålidelige $\mathrm{i}$ national henseende, var det hans princip ikke at blande sig i deres partipolitiske linie. Således var det ikke altid klart for konkurrerende blade, at der bag de forskellige » Tarngesellschaften«, der kontrollerede 
dem økonomisk, i virkeligheden stod én og samme ejer, nemlig Winkler dvs. staten. Denne partipolitiske neutralitet sikrede Winkler og Konkordia konstant opbakning fra det parlamentariske tilsynsråd, og denne nære forbindelse med de parlamentariske instanser sikrede samtidig Konkordia en gnidningsløs financiering. ${ }^{9}$

Som Winklers befuldmægtigede i den konkrete sag optrådte Wacker, som det lykkedes takket være sine forbindelser i Flensborg og formentlig under henvisning til, at statslig opbakning bag projektet var sikret, at få oprettet et $\mathrm{GmbH}$, et anpartsselskab, med deltagelse dels af Flensburger Nachrichtens hidtidige ejere, Kommanditgesellschaft L. P. H. Maass, dels af 36 personer eller firmaer, herunder $» 34$ af de betydeligste og største tyske industriforetagender, banker og handelsfirmaer« i Flensborg og omegn. ${ }^{10}$ Blandt anpartshaverne var også Wacker, som i eget navn forvaltede en af Konkordia ejet anpart. Dette selskab, Deutscher Verlag, skulle forpagte Flensburger Nachrichten for en nærmere fastsat periode, ligesom det samtidig købte retten til navnet Schleswigsche Grenzpost, som herefter trådte i likvidation. Udadtil præsenteredes dette som en sammenlægning af de to blade, hvis første fælles udgave udkom den 25. oktober 1922. ${ }^{11}$

Fra dansk side ytredes åbent mistanke om et statsligt engagement $\mathrm{i}$ Flensburger Nachrichten, hvilket altså heller ikke var uden grundlag; men staten var dog endnu slet ikke involveret i det omfang, som det senere skulle blive tilfældet. Flensburger Nachrichten kunne således den 26. oktober ikke helt usandfærdigt skrive, at samtlige anpartshavere var gode slesvigere. Udover Wackers anpart bestod statens, dvs. Winklers, indsats primært i hjælp ved financiering og fremskaffelse af papirleverancer, en støtte, som ikke blot kom Flensburger Nachrichten, men hele den tyske grænsepresse til gode. ${ }^{12}$

Næppe havde det ny foretagende etableret sig, før inflationen for alvor brød løs i Tyskland, og oprettelsen af GmbH'et var i sig selv ikke nok til at redde avisen igennem denne ny storm. Trykkeriet skulle desuden moderniseres for at være rentabelt, hvilket kun kunne ske ved at pumpe yderligere kapital i bladet. Winklers og Wackers plan gik først ud på via en fusion med yderligere blade at redde, hvad reddes kunne. Den 20. marts 1923 lod Winkler og Wacker oprette og registrere et nyt "Tarngesellschaft«, Deutscher Schutzverlag GmbH med sæde i Berlin, der skulle administrere den økonomiske støtte til den slesvigske presse. Eneste anpartshavere var Winkler og Wacker, der også begge figurerede som forretningsførere. I oktober 1923 udformedes dels en "Treuhanderklärung« mellem Schutzverlag og Wacker, hvoraf 
fremgår, at Schutzverlags kapital tilhørte Konkordia, dels en "Treuhandvertrag« mellem Konkordia og Deutscher Schutzverlag, hvoraf fremgår, at Wackers engagement i slesvigske presseanliggender foregik for Konkordias regning og på Konkordias vegne. ${ }^{13}$

Hermed har vi dog foregrebet begivenhedernes gang en smule. Allerede den 13. august 1923 havde Winkler og Wacker i fællesskab indgivet en ansøgning til den preussiske statsregering om støtte til Flensburger Nachrichten, og den 24. september rettede Wacker på Konkordias vegne en lignende ansøgning til rigsfinansministeriet. Begge instanser viste sig velvillige og fra efteråret 1923 flød stadig større summer i retning Flensborg. Da inflationen imidlertid samtidig var på sit kulminationspunkt, er det overordentlig vanskeligt at konstatere, hvor betydningsfulde beløb, der var tale om. ${ }^{14} \operatorname{Pr}$. 1. april 1924 gik Deutscher Verlag imidlertid over til at opgøre kapital og regnskaber i guldmark, hvilket bidrager væsentligt til at øge overskueligheden. ${ }^{15}$ Den hidtidige stamkapital på $920.000 \mathrm{M}$ omregnedes til 46.000 guldmark. Samtidig foretoges en kapitaludvidelse på 2.670 guldmark, som for Deutscher Verlags regning overdroges Maassarvingerne. Samtidig udtrådte Kommanditgesellschaft L. P. H. Maass af GmbH'et, og i stedet indtrådte arvingerne som enkeltanpartshavere i Deutscher Verlag. ${ }^{16}$

Den 10. maj 1924 købte Deutscher Verlag forlag, lokaler og trykkeri for 100.000 guldmark af familien Maass - til afbetaling over en relativt kort periode. ${ }^{17} \mathrm{Da}$ Wacker - på Konkordias vegne - siden oktober 1923 havde udlagt større beløb for Deutscher Verlag, end selskabet ville kunne tilbagebetale, løstes dette problem ved, at de øvrige anpartshavere afstod en del af deres anparter til Wacker. Resultatet blev, at Wacker af den samlede kapital på 48.670 guldmark herefter kontrollerede 29.280 , dvs. ca. $60 \%$ af stamkapitalen. Hermed var forpagtningsaftalen tillige bortfaldet, og GmbH'et var nu også formelt Flensburger Nachrichtens ejer. ${ }^{18}$

Denne ordning, som her etableredes, kom senere til at udløse voldsomme stridigheder mellem Winkler/Konkordia på den ene side og Wacker og de flensborgske anpartshavere - dog undtaget familien Maass - den såkaldte Flensborg-gruppe på den anden. Kort fortalt havde de flensborgske anpartshavere allerede ved oprettelsen af forpagtningsaftalen i 1922 ladet indsætte en bestemmelse i Deutscher Verlags vedtægter om, at Wackers og Maassarvingernes anparter ikke kunne afhændes eller overdrages uden de øvrige anpartshaveres accept. Hensigten hermed var selvfølgelig at sikre den lokale indflydelse på 
avisen. I Flensborg betragtede man Wacker som indehaver af majoriteten i selskabet, mens Winkler omvendt kun anså Wacker for en stråmand, der til enhver tid ville kunne skiftes ud. Wacker, der indtil 1925 havde boet i Berlin, flyttede i 1925 til Flensborg og overtog samtidig posten som leder af Deutscher Verlag. Mens han hidtil kun havde været tilsynsrådsformand (de øvrige medlemmer var næstformanden Ernst Schröder, Ernst Maass som repræsentant for Maassarvingerne samt C. C. Christiansen og Hermann G. Dethleffsen for Flensborg-gruppen) overtog han nu også den daglige forretningsmæssige ledelse. Dette skal ses på baggrund af utilfredshed fra tilsynsrådets side med Ernst Maass' indsats på denne post. ${ }^{19}$

Hermed var Flensburger Nachrichtens overgang fra familien Maass' hænder til Deutscher Verlag afsluttet. Det betød imidlertid ikke, at der nu blev ro bag kulisserne på bladet. Det egentlige problem viste sig at være bestemmelsen om, at en anpart ikke kunne overdrages eller afhændes uden videre. Lederne af Flensborg-gruppen hævdede senere, at den socialdemokratiske Braun/Severing-regering i Preussen i midten af 1920 'erne, ansporet af det flensborgske socialdemokrati, skulle have iværksat en aktion med henblik på at bringe Nachrichten under regeringskontrol. Der skulle således have været tale om flere forgæves forsøg på at udøve pres for at få avisen til at indtage en mere regeringsvenlig holdning. Protester fra Berlin skulle det første gang være kommet til i oktober 1926. Årsagen var et par artikler, som man fandt for højreorienterede, og som rummede kritik af den preussiske regerings foranstaltninger. Regeringen havde protesteret, hvorfor Winkler havde søgt at gribe ind. ${ }^{20}$

Dette skulle desuden have været led i en bredere anlagt offensiv for at bringe flest mulige tyske aviser under regeringskontrol eller -indflydelse. Dethleffsen og Christiansen hævdede således i 1933, at Winkler af indenrigsminister Severing og Ministerialrat Rathenau skulle have fået besked på at udnytte »sin« majoritet $\mathbf{i}$ Flensburger Nachrichten til at ændre bladets linie. Winkler skulle i december 1926 være kommet til Flensborg ledsaget af præsidenten for Reichsrechnungshof, Müller. Flensborg-gruppen gjorde ham ved den lejlighed klart, at »han« ingen majoritet besad, hvor igennem han kunne udøve nogensomhelst indflydelse. Statens anparter var placeret på Wackers navn, og denne støttede bladets nationalistiske og antisocialdemokratiske linie. I kraft af vedtægternes $\S 4$ kunne Flensborg-gruppen således disponere over statens anparter. Man ville også have understreget over for Winkler, at det fra begyndelsen havde været klart, at det af staten indskudte beløb 
ikke måtte bruges til at skaffe ikke-lokale kredse indflydelse på bladet, og at han selv havde accepteret, at det måtte være sådan. Winkler skulle have indvendt, at det jo heller ikke var meningen at indskrænke de flensborgske anpartshaveres rettigheder, men blot at give den bestående ordning en form, så de flensborgske særrettigheder kunne udøves i tilsynsrådet, sådan at han kunne være bekendt at "vise dem frem «.21

Da dette viste sig umuligt, besluttede Winkler sig i stedet til at gå rettens vej. Den 11. april 1928 opsagde han Wacker som "Treuhänder" og fjernede denne fra Deutscher Schutzverlag. Da Wacker nægtede at aflevere "sine» anparter til Schutzverlag - hvad han ellers skriftligt havde forpligtet sig til ${ }^{22}$ - lagde Winkler i efteråret 1928 sag an mod Wacker med krav om at få Schutzverlag "genindsat i sine retmæssige ejerrettigheder «, således at Wacker kunne skiftes ud med en anden "Treuhänder«. At formålet hermed skulle være at kunne udøve indflydelse på den redaktionelle linie, benægtede Winkler derimod. ${ }^{23}$

Avisens ledelsesstruktur så på dette tidspunkt således ud, at et af tilsynsrådet udpeget forretningsudvalg bestående af Wacker, Dethleffsen og Christiansen varetog den øverste ledelse af såvel redaktion som forlagets teknisk-forvaltningsmæssige side. ${ }^{24} \mathrm{På} \mathrm{grund} \mathrm{af} \mathrm{striden} \mathrm{med}$ Winkler besluttede dette forretningsudvalg at tage kontakt med dr. Hugo Eckener - en svigersøn til L. P. H. Maass - som repræsenterede familien Maass' anparter, og drøfte en overtagelse af disse. Selv om Eckener hidtil havde støttet Winkler og gentagne gange givet udtryk for forbitrelse over den måde, hvorpå familien var blevet behandlet $\mathrm{i}$ årene siden $\mathrm{GmbH}$ 'ets oprettelse, var han dog ikke uinteresseret i et eventuelt salg. Han lovede således at forhøre sig hos de øvrige familiemedlemmer, og hvis disse var indforståt, at opstille et salgstilbud. Hvis retten skulle afgive en kendelse til fordel for Deutscher Schutzverlag, nåtte forhandlingerne selvfølgelig suspenderes. ${ }^{25}$

Den 18. december 1928 forkyndte retten i Flensborg - Kammer für Handelssachen - den med spænding ventede dom, som gik Winkler imod. Kort tid senere - den 11. januar 1929 - meddelte dr. Eckener, at familien ikke ville sælge. ${ }^{26}$ Modsætningsforholdet mellem Wacker og familien Maass havde bl.a. ført til, at disse anpartshavere på generalforsamlingen i 1928 havde støttet Winkler i striden om statens anparter og ladet sig repræsentere af dennes advokat på den ordinære generaIforsamling. På generalforsamlingen den 13. juni 1929 afviste de samme anpartshavere regnskabet under henvisning til, at tilbagebetaling af driftskapital ikke kunne betragtes som dividendeudbetaling. ${ }^{27}$

Processen mellem Winkler og Wacker blev fort helt igennem til 
højeste instans, Reichsgericht, og samtlige instanser fastslog, at selv om det var klart, at Deutscher Schutzverlag rent økonomisk ejede de omstridte anparter, så måtte Deutscher Verlag GmbH's vedtægter også være gældende for disse anparter, som hermed kom til at svæve fuldstændigt i luften. Schutzverlag ejede anparterne, men kunne ikke disponere over dem. Wacker ejede ingenting, men besad dispositionsretten, sålænge han havde Flensborg-gruppen i ryggen. Retten afviste også at anvise anden vej ud af denne situation end at opfordre parterne til selv at søge at blive enige. ${ }^{28}$ Hermed var situationen låst fast, og gentagne forsøg på at finde en for alle parter tilfredsstillende løsning faldt negativt ud. Uanset at Wacker var blevet opsagt af Schutzverlag, blev han siddende som forlagsleder og tilsynsrådsformand. Først med den nazistiske magtovertagelse kom der påny bevægelse $i$ tingene. Med nazisternes overtagelse af regeringsmagten i såvel Riget som Preussen var det nu »deres « aktiemajoritet, der hang i luften. Dette kunne man naturligvis ikke tolerere og skred til handling.

\section{Ensretningen}

Beklageligvis har det ikke været muligt at konstatere, hvem der rejste spørgsmålet om en nazificering af Flensburger Nachrichten - mest sandsynligt forekommer det, at Winkler tog initiativet - eller om der eventuelt var tale om en koordineret indsats over for blade, hvori staten besad en betydelig aktiepost eller majoriteten. ${ }^{29}$ Fastslås kan, at der formentlig i april 1933 - var planlagt et møde i det nyoprettede propagandaministerium vedrørende Flensburger Nachrichten mellem Winkler - der hurtigt havde fået sig arrangeret med de ny magthavere Gauleiter og overpræsident Lohse fra Kiel, statssekretær Funk samt Ernst Schröder og muligvis endnu flere. Dette møde blev imidlertid ikke til noget, da Lohse var forhindret. Winkler modtog senere besked fra Funk om, at mødet var udskudt på ubestemt tid, hvorfor han burde kontakte Lohse med henblik på at arrangere et møde med denne $\mathrm{i}$ Kiel. ${ }^{30}$

Til Lohses orientering sendte Winkler ham en kort redegørelse for Deutscher Schutzverlags rolle i forbindelse med Flensburger Nachrichten, hvori han skildrede udviklingen siden 1921 og samtidig fremlagde et program for, hvorledes den "retmæssige ejer«, dvs. den preussiske stat, kunne bringes $i$ besiddelse af sin ejendom, majoriteten i Flensburger Nachrichten/Deutscher Verlag GmbH. Winkler mente, at følgende indgreb ville være absolut nødvendige: Lohse skulle som repræsentant 
for den preussiske stat sørge for, at Schutzverlags anparter blev overdraget af Wacker til en eller flere ny befuldmægtigede "Treuhänder«. Lettest ville det efter Winklers mening glide, hvis man betragtede den omstridte afståelse af disse anparter som ikke-havende-fundetsted. Tilsynsrådet burde endvidere straks indkalde til en ekstraordinær generalforsamling med følgende dagsorden:

1) godkendelse af anparternes overførsel,

2) ændring af selskabets vedtægter og nyvalg til tilsynsrådet, hvori de ny befuldmægtigede skulle have sæde og en af disse være formand.

Vedtægtsændringerne skulle sikre, at den preussiske regerings besiddelse af majoriteten også kunne omsættes til reel kontrol med selskabet, en kontrol, som skulle varetages af det nyvalgte tilsynsråd. For at realisere denne plan ville det, påpegede Winkler, vare nødvendigt at indvirke kraftigt på de herrer Dethleffsen og Christiansen, der dels var befuldmægtigede for Flensborg-gruppen, dels Wackers sikre støtter. Når nyordningen var gennemført, måtte det næste skridt være at foretage en gennemgribende revision af selskabets regnskaber for at kontrollere Wackers virksomhed som forlagsleder, som Winkler og Schutzverlag på grund af omstændighederne ikke havde kunnet følge. Winkler vedlagde samtidig en fortegnelse over anpartshaverne og anparternes størrelse. ${ }^{31}$

Winklers fremstilling, der formodentlig var udarbejdet med henblik på det aflyste møde i Berlin, ses desværre ikke at være blevet kommenteret af Lohse. Men som det vil fremgå af nedenstående, må Lohse og hans overordnede have delt Winklers opfattelse af, hvad der burde gøres. Den 12. maj - kun to dage efter Winklers henvendelse til Lohse - afgik nemlig to skrivelser fra den presussiske ministerpræsident Görings kancelli til Kiel, en til Lohse personligt og en officielt til overpræsidenten. Heraf fremgår, at Lohse mundtligt over for det preussiske statsministerium havde anmodet om fuldmagt til at indsætte en statskommissær ved Flensburger Nachrichten med henblik på at gennemføre præcis, hvad Winkler havde foreslået i sit memorandum af 20. april 1933. På baggrund af denne hurtige handlen er det givet, at ministerpræsidentens kancelli har været underrettet om sagens aspekter i forvejen. Lohse anmodedes om at indskærpe den pågældende kommissær, at denne havde at holde sig til sit kommissorium. Specielt måtte han ikke gribe ind $\mathrm{i}$ avisens almindelige drift, før den planlagte revision af regnskaberne var afsluttet, og kun såfremt revisionens resultat viste, at en sådan indgriben var nødvendig. Var dette tilfældet, skulle 
juridiske komplikationer $\mathrm{i}$ form af klager fra driftsledelsens side undgås. Lohses opgave var at overvåge kommissærens arbejde og at holde Berlin underrettet om udviklingen. Operationen ønskedes i øvrigt afviklet så hurtigt som muligt. ${ }^{32}$

Den 15. maj 1933 udnævnte Lohse købmand Herbert Jensen fra Flensborg til statskommissær ved Flensburger Nachrichten på anbefaling af NSDAP's Ortsgruppenleiter i Flensborg, maskiningeniør Adler, og underrettede de kompetente instanser herom. I en skrivelse til ministerpræsidenten anførte Lohse, at det ikke på forhånd var muligt at sige noget om sagens varighed, men at kommissæren var blevet bedt om at indberette løbende om udviklingen. ${ }^{33}$ Overpræsidentens meddelelse til Jensen om udnævnelsen rummer intet overraskende. Kommissoriet og kommentarerne var nøjagtige gentagelser af ministerpræsidentens skrivelse af 12 . maj $1933 .^{34}$

Desværre har det ikke været muligt at få indblik i de overvejelser og diskussioner, som må være gået forud for Jensens udnævnelse; men det er indlysende, at Jensen må være blevet kontaktet og have accepteret at påtage sig opgaven inden udnævnelsen. Han må også have fået nærmere instrukser om, hvorledes han burde forholde sig. Endnu samme dag, som han havde modtaget sin beskikkelse, opsøgte Jensen Albert Wacker for at underrette denne om sin udnævnelse. Wacker skulle være blevet meget overrasket over denne forholdsregel, men havde ellers ikke gjort knuder, således at der ikke var nogen grund til videre indgriben. Risiko for økonomiske besvigelser eller fjernelse af værdier fra selskabet mente Jensen og hans juridiske rådgiver dr. Kurt Elsner ikke bestod. Man havde derfor blot meddelt Wacker og forretningsfører Bethke, at transaktioner, der gik ud over rammerne for den daglige drift, ikke måtte finde sted. Revisionsselskabet var gået i gang med regnskaberne den 17 . maj; Jensen regnede med, at dette arbejde på grund af firmaets temmelig gammeldags bogføringspraksis ville tage et par uger.

Jensen havde også fundet det rigtigst på baggrund af den indviklede juridiske situation at tage kontakt med Flensborg-gruppens ledende folk for at undersøge, om de skulle være rede til at acceptere Deutscher Schutzverlags overtagelse af Wackers anparter - hvilket jo var nødvendigt i følge vedtægternes $\S 4$ og rigsretskendelsen. På Elsners kontor havde han haft en samtale med C. C. Christiansen den 18. maj, hvorunder Jensen og Elsner havde fremlagt deres krav. Christiansen havde erklæret sig villig til at forhandle om anparternes overførsel, men havde understreget, at hvis der også var tale om at fjerne Wacker fra 


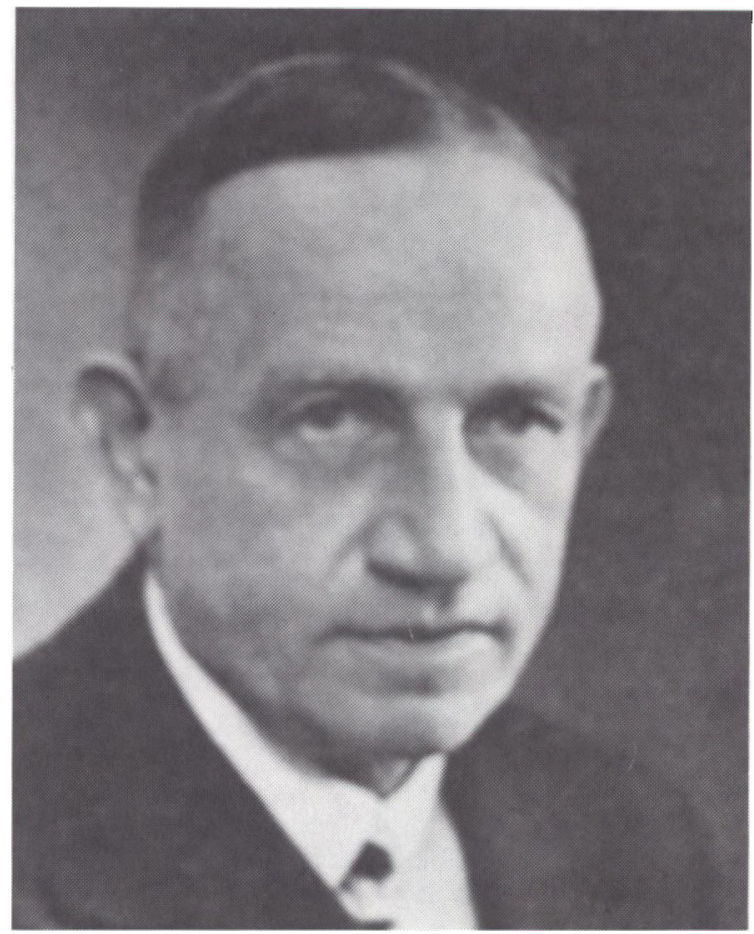

Fabrikant Chr. C. Christiansen, en af de flensborgske anpartshavere $i$ Flensburger Nachrichten, der forgaves forsagte at undgå den statslige overtagelse af bladet. Efter 1945 var han en hovedkraft $i$ det tysk-nationale organisationsarbejde $i$ Sydslesvig. (Dansk Centralbibliotek for Sydslesvig).

virksomheden, ville man ikke være med. Jensen var derfor noget i tvivl om, hvor vidt man ville kunne finde en ordning med de flensborgske anpartshavere, og mente derfor, at man burde vente med at indkalde til generalforsamling til revisionsberetningen forelå. Denne ville sandsynligvis indeholde ting, som kunne gøre det lettere at øve indflydelse på Flensborg-gruppen. ${ }^{35}$

Lohse tilsluttede sig Jensens vurdering af situationen, måske ikke mindst på baggrund af en skrivelse fra Elsner, hvor denne gennemgik den juridiske situation omkring Flensburger Nachrichten og Deutscher Schutzverlag. Elsner fastslog således, at Wacker og Co. på grund af rigsretskendelsen fra 1928 stod meget stærkt, hvorfor man intet ville opnå ved at indkalde til generalforsamling. Flensborgerne ønskede at bevare deres blad uafhængigt og ville blot afvise regeringens ønsker. ${ }^{36}$ Også revisionsfirmaet indberettede den 19. maj til overpræsidenten. Efter to dages arbejde havde revisorerne ved kasserevisionen fundet et antal ikke-bogførte bilag på ialt 2.690,90 RM vedrørende forskud til det overordnede personale, som delvist stammede helt tilbage fra 1929. 
Herefter ville man så gå igang med en kontrol af tabs- og gevinstkontoen, specielt omkostningskontoen med henblik på udgifter til de ledende personer og en undersøgelse af firmaets finanser helt tilbage til 1924. Dette ville ialt tage mellem 10 og 14 dage. $^{37}$

Det er altså klart, at indgrebet over for Flensburger Nachrichten havde et videre sigte end blot at sikre den preussiske stat $=$ Deutscher Schutzverlag $=$ Winkler besiddelsen af dispositionsretten over sin ejendom. Wacker skulle ud. Formålet med revisionen var heller ikke blot at orientere den retmæssige - hidtil udelukkede ejer - af majoriteten i selskabet om dets financielle situation, men lige så meget at finde materiale, der kunne bruges til at tvinge Wacker og Flensborg-gruppen til at falde til føje. Lohse bifaldt som nævnt Jensens fremgangsmåde, hvilket han orienterede såvel denne som Berlin om. ${ }^{38}$

Den 30. maj skrev Jensen til overpræsidenten, at det nu så ud til, at Flensborg-gruppen ønskede en mindelig ordning. Dette kunne man gå med til, "sofern die Leute unsere Forderung bedingungslos annehmen«. Om et par dage mente han at kunne have mere nyt. ${ }^{39}$ Den 2 . juni kunne han oplyse, at revisionen ville være afsluttet samme dag. Der syntes ikke at kunne påvises nogen form for besvigelser; men revisionsberetningen bød dog på holdepunkter nok for at kunne udøve det nødvendige pres, såfremt en mindelig ordning ikke kunne opnås. Dagen forinden havde han haft et møde med C. C. Christiansen og Hermann G. Dethleffsen, som havde erklæret, at de helt og fuldt stod bag den "nationale regering«. De var rede til at give garantier for, at avisen ville arbejde efter regeringens retningslinier ved at ansætte nazistiske redaktører og ved at stille udbyttet fra Wackers/Deutscher Schutzverlags anparter til rådighed for grænsekampen. Til gengæld forlangte man »særlige garantier for Wacker«. Elsner og Jensen havde taget dette til efterretning, men ikke ladet tvivl bestå om, at de måtte insistere på Wackers fjernelse og de krævede vedtægtsændringer. Jensen havde givet en frist til den 7. juni kl. 9 om morgenen til at gå ind herpå. Imødekom Flensborg-gruppen ikke betingelsesløst disse krav, havde Jensen gjort de herrer klart, at han så ville finde andre veje at gå. For sit eget og Elsners vedkommende ønskede han et møde med Lohse - helst den 9. maj - for at drøfte nærmere detaljer, ikke mindst vedrørende reorganiseringen af tilsynsrådet. ${ }^{40}$

Flensborg-gruppen var dog endnu ikke til sinds at give sig. Nok var man villig til samarbejde og til at acceptere en nazificering af den redaktionelle linie, men ikke til at give fuldstændig afkald på den kontrol med bladet, som man havde sikret sig via selskabets vedtægter 
og Wackers støtte. Den 6. juni sendte C. C. Christiansen og H. G. Dethleffsen på bladets vegne et omfattende memorandum til Jensen som svar på dennes ultimatum af 1 . juni. De understregede, at juridisk var sagen ganske klar, og at de følgelig havde retten på deres side. Argumentationen $\mathrm{i}$ ørigt er der ingen grund til at gå nærmere ind på her. Interessante var derimod de forslag, som fremsattes for at nå frem til et kompromis. ${ }^{41}$

Flensborg-gruppen betragtede Wackers person som afgørende for Flensburger Nachrichtens trivsel. Bladets særlige grænsepolitiske ansvar havde medført, at det ikke var blevet drevet som en almindelig kapitalistisk erhvervsvirksomhed. Den støtte, som bladet i sin tid havde modtaget, og som nu udgjorde Wackers anparter, havde bestået i inflationspenge, hvis værdi reelt kun svarede til fem jernbanevogne med papir. Foretagendets øvrige værdier var skabt »ved flensborgsk arbejde«. Christiansen og Dethleffsen fandt det derfor aldeles urimeligt, at en så ringe investering 10 år senere skulle kunne medføre statens overtagelse af hele virksomheden. Netop for at gardere sig mod indblanding havde vedtægterne fået den særlige form. De kunne ikke tro, at en "national regering" på grundlag af informationer fra regeringen Braun/Severings tidligere tillidsmænd - dvs. Winkler - og uagtet en højesteretskendelse ville forlange, at flensborgerne skulle prisgive, hvad de så længe havde kæmpet for, og fjerne hele grundlaget for bladets arbejde.

Såfremt Jensen på statens vegne ville erkende, at Flensburger Nachrichten ingensomhelst forpligtelse havde til nogen form for indrømmelser, kunne der være grundlag for forhandlinger. Christiansen og Dethleffsen tænkte sig, at der kunne grundlægges en "grænsetysk fond«, der skulle overtage de omstridte anparter. De erkendte, at tidligere tiders politiske betænkeligheder med hensyn til statens hensigter nu var bortfaldet; men ikke desto mindre burde avisens historiske grundlag og dens uafhængige status fastholdes for at undgå et indtryk af, at Flensburger Nachrichten var »et af regeringen afhængigt forvaltningsredskab«. Et sådant indtryk ville skade forholdet til læserne og også den opgave, som man "af dybeste overbevisning « havde påtaget sig efter den 30. januar 1933, nemlig at vinde læserne for den »nationale stat « og den nationalsocialistiske bevægelses tanker. Også i grænsepolitisk henseende mente de, at bladet ville være bedst tjent med at bevare sin uafhængige stilling. Bestyrelsen for den foreslåede grænsetyske fond burde sammensættes ligeligt af repræsentanter udpeget af regeringen og 
Flensborg-gruppen, hvilket ville udelukke majorisering. Bladets linie skulle følge regeringen uden forbehold, hvilket kunne demonstreres ved en ændring af tilsynsrådets sammenhæng. Flensborg-gruppen kunne acceptere en vetoret for statens repræsentanter, hvad angik den redaktionelle personalepolitik, mod en tilsvarende vetoret for sig selv, hvad angik de øvrige ansatte. Christiansen og Dethleffsen lagde ikke skjul på, at nøgleproblemet var Wackers person, som de tillagde et utal af dyder. ${ }^{42}$ I en vedlagt resolution fra de ansatte til tilsynsrådet med 62 underskrifter erklærede personalet sin fulde tillid til Wacker. Hvis denne blev fjernet, ville man føle det bestående tillidsforhold mellem ledelse og ansatte truet. ${ }^{\mathbf{4 3}}$

Skal man uddrage essensen af det 12 maskinskrevne sider lange memorandum, må resultatet blive følgende: Flensborg-gruppen var rede til $\mathrm{i}$ redaktionel henseende at lade Flensburger-Nachrichten nazificere og ensrette, hvis blot man kunne bevare den reelle kontrol med virksomheden. Jensens ultimatum var dermed afvist. De givne indrømmelser gjaldt netop ikke de punkter, som var afgørende i Jensens kommisorium. Tydeligt er, at Christiansen og Dethleffsen på dette tidspunkt endnu ikke havde forstået, hvad for folk de havde fået med at gøre. Samme morgen som Jensen modtog Flensborg-gruppens svar - den 7. juni - førte han en telefonsamtale med Oberregierungsrat Romig i overpræsidiet. Desværre har det ikke været muligt at fastslå, hvad der blev talt om, men i hvert fald sendte Jensen samme dag memorandum'et til Lohse, ledsaget af en indtrængende anmodning om, at han og Elsner måtte få lejlighed til en personlig samtale med overpræsidenten. ${ }^{44}$

Desværre indtræder netop på dette tidspunkt en lakune i materialet, hvilket er ekstra beklageligt, som det af det følgende vil fremgå, at en afgørende udvikling i sagen netop fandt sted omkring midten af juni 1933. Det kan således ikke konstateres, om det lykkedes Jensen og Elsner at opnå det ønskede møde med Lohse, omend det er sandsynligt. Dette ville kunne forklare hullerne $\mathrm{i}$ materialet og den pludselige udvikling i sagen. Konstateres kan, at Jensen den 9. juni sendte en afskrift af Flensborg-gruppens memorandum til Julius Mundhenke i Berlin, prokurist i Konkordia og »tilfældigvis« også forretningsfører for Cura Revisionsgesellschaft $\mathrm{GmbH}$ - det selskab, som foretog revisionen af Flensburger Nachrichtens regnskaber - med anmodning om en stillingtagen. Mundhenke svarede allerede den følgende dag med en skriftlig redegørelse, som i hovedsagen var en fuldstændig afvisning 
af memorandummets historiske fremstilling og juridiske argumentation. ${ }^{45}$ Manglen på konkrete forslag gør imidlertid dette dokument mindre interessant $\mathrm{i}$ denne sammenhæng.

Derimod fandt der en af de følgende dage - formodentlig den 13. eller 14. - en telefonsamtale sted mellem Lohse og Winkler, hvorunder det aftaltes, at Winkler skulle fremsende et forslag om, hvad der burde gøres i sagen Flensburger Nachrichten. Et sådant forslag afgik fra Berlin til henholdsvis Lohse og Jensen den 15. juni, og i overpræsidentens arkiv findes et sådant udateret og usigneret forslag fra juni 1933, som er godkendt af Lohse. ${ }^{46}$ Der kan næppe være tvivl om, at dette dokument er identisk med Winklers forslag og med en instruktion fra Lohse til Jensen, som kommissæren den 26. juni bekræftede at have modtaget. ${ }^{47}$

Hovedpunkterne i denne var følgende: Wacker skulle afstå sine anparter, nedlægge sit tilsynsrådsmandat, straks indstille sin virksomhed i selskabet og aflevere alle akter, bøger o.lign., som han måtte være i besiddelse af. Dernæst ville han blive opsagt pr. 30. september 1933. Skulle Wacker vægre sig eller søge at trække sagen i langdrag, skulle det gøres ham klart, at det ville få konsekvenser for hans person. Derefter skulle forretningsfører Bethke indkalde til ekstraordinær generalforsamling på normal vis. Hovedpunkterne på dagsordenen skulle være: godkendelse med tilbagevirkende kraft af Wackers overdragelse af sine anparter til dr. Elsner, de allerede omtalte vedtægtsændringer og opløsning af og nyvalg til tilsynsrådet.

Den vigtigste planlagte vedtægtsændring var naturligvis fjernelsen af bestemmelsen om Flensborg-gruppens vetoret ved afhændelse eller overdragelse af anparter. Fremover skulle sådanne transaktioner kunne finde sted, blot flertallet på en generalforsamling accepterede det. Dette betød i realiteten vetorettens overgang fra Flensborg-gruppen til Deutscher Schutzverlag, dvs. staten. Det ny tilsynsråd skulle bestå af seks personer, hvoraf fire skulle være medlemmer af NSDAP og to repræsentanter for Flensborg-gruppen. Eventuelt skulle et syvende mandat forbeholdes den forhenværende ejer, Ernst Maass, som havde ret til et sådant. Formand skulle dr. Elsner være. Samtidig med indkaldelsen til generalforsamlingen skulle Christiansen og Dethleffsen have besked om at afgive en forpligtende erklæring om, at de på Flensborg-gruppens vegne ville stemme for de planlagte forholdsregler. Skulle de herrer imidlertid mod forventning gøre knuder, ville man meddele dem, at visse punkter i revisionsberetningen i så fald ville blive draget frem på generalforsamlingen, hvorefter de ansvarlige medlem- 
mer af tilsynsrådet ville blive draget til ansvar hensynsløst $i$ enhver henseende. ${ }^{48}$

Jensen gik straks i gang med at udføre sin instruks, og den 26 . juni kunne han underrette overpræsidenten om, at der nu var sket et afgørende gennembrud. Den 21. juni havde han opsøgt Wacker og forlangt dennes anparter udleveret og officielt afstået til dr. Elsner. ${ }^{49}$ Wacker havde svaret, at han allerede havde afstået anparterne til Winkler. Jensen havde dernæst sat sig $\mathrm{i}$ forbindelse med Berlin og bedt om at få papirerne overført på dr. Elsners navn, hvilket senere skulle godkendes på generalforsamlingen. På kravet om nedlæggelse af tilsynsrådsmandatet havde Wacker svaret, at han officielt ville meddele tilsynsrådet, at han på grund af indsættelsen af en statskommisær var forhindret $i$ at udøve sit mandat. Jensen mente ifølge loven at have beføjelse til at afsætte Wacker uden videre. Opsigelsen var forkyndt, og Wackers virksomhed i firmaet ophørt. Alle bøger, akter osv. var afleveret på behørig vis. Indbydelserne til generalforsamlingen, som skulle finde sted den 11. juli kl. 17 på Bahnhofshotel Flensburg, var udsendt korrekt, ligesom Jensen havde taget kontakt med enkelte anpartshavere, som han vidste, var utilfredse med den måde, hvorpå bladet hidtil var blevet kørt. Han havde derved opdaget, at Christiansen og Dethleffsen forsøgte at opnå fuldmagt til at repræsentere alle Flensborg-gruppens medlemmer på generalforsamlingen - hvilket i parantes bemærket altid havde været sædvane. Var dette lykkedes, ville man have været tvunget til at forhandle med disse herrer alene. ${ }^{50}$

Jensen havde straks udsendt en skrivelse til alle medlemmer af Flensborg-gruppen, hvori han betegnede denne fremgangsmåde som stridende groft mod regeringens ønsker, eftersom formålet kun kunne være at få de øvrige anpartshavere til at stemme imod de af regeringen ønskede vedtagelser. Christiansen og Dethleffsen havde på et møde med Jensen og Elsner den 26. juni erklæret sig bestyrtet over Jensens skrivelse og benægtet, at deres handlemåde kunne betragtes som sabotage mod Jensens planer. Hensigten havde kun været - de var jo i forvejen befuldmægtigede for Flensborg-gruppen - at opnå en tillægsfuldmagt, ved hvilket Flensborg-gruppens fuldmagt blev overdraget til en notar. Jensen bemærkede, at resultatet altså ville være blevet, at "vi havde måttet holde vor generalforsamling alene med notaren«. Han havde gjort Christiansen og Dethleffsen klart, at dette ville være uacceptabelt, og ventede derfor, at generalforsamlingen ville finde sted "på den af os forudsete måde«. Christiansen og Dethleffsen havde ganske vist erklæret, at de agtede sig til Berlin for at klage en gang til, 
og bedt om Jensens tilladelse hertil. Denne havde svaret, at de kunne rejse, hvorhen de ville, men at det intet ville ændre. Endvidere ville de gerne have en ny samtale med Jensen, når de kom tilbage, hvilket han gerne tilstod dem, da han antog, at rejsens resultat ville overbevise dem om det forgaves i deres anstrengelser. Til slut kunne Jensen meddele, at den af Lohse udpegede ny grænsepolitiske redaktør ved Flensburger Nachrichten, Ernst Grunow, var ankommet fra København, således at han kunne være indarbejdet, når udskiftningen af redaktionen fandt sted. ${ }^{51}$

Denne indberetning er interessant af flere grunde. Det er klart, at der var sket et gennembrud for kommissæraktionen. Det vigtigste mål, at opnå kontrol over Wackers anparter, var nået, ligesom det så ud til, at generalforsamlingen ville få det af regeringen ønskede forløb. Spørgsmålet hvorfor kan desværre ikke besvares med sikkerhed. Det kunne se ud til, at Jensens ubestemte, men tydelige trusler havde gjort deres virkning; men dette forklarer næppe Wackers kapitulation, som må ses på baggrund af års sej kamp. Afgørende var Flensborggruppens holdning. Nægtede denne at godkende Wackers overdragelse af anparterne, ville kommissæren være lige vidt. Der må altså være foregået noget, som har fået det til at gå op for Wacker og Co., at deres stærke juridiske stilling under de gældende forhold faktisk var af mindre betydning. Selv om Christiansens og Dethleffsens rejseplaner kunne tyde på, at de endnu ikke helt havde opgivet håbet om at undgå statens overtagelse af virksomheden, var det dog tydeligt, at det ikke var formaljuridiske, men politiske argumenter, de agtede at fremføre i Berlin. Det ser desuden ud til, at de endelig havde opgivet at redde Wackers position.

Wacker selv havde nok bøjet sig for det uafvendelige, men var ikke indstillet på helt uden sværdslag at lade sig skubbe ud i mørket. Efter deres samtale den 21. juni havde Herbert Jensen den 23. sendt ham en skrivelse, som refererede deres diskussions forløb, og som Jensen ønskede en godkendelse af $\mathrm{i}$ form af en kvitteringsskrivelse. ${ }^{52}$ Wacker svarede den 26. juni, at han jo - som også nævnt af Jensen i indberetningen til Lohse - efter at have udstedt sin fuldmagt til Winkler ikke mere disponerede over de omstridte anparter. En egentlig afståelse, som nu kunne foretages af Winkler på hans vegne, skulle imidlertid først godkendes af generalforsamlingen. Wacker kan altså have håbet, at generalforsamlingen ville nægte sin godkendelse. Han benægtede, at Jensen skulle have forlangt, at han skulle nedlægge sit tilsynsrådsmandat, men tilføjede, at han - da han i praksis var afskåret fra at udøve sin 
funktion - havde bedt Christiansen og Dethleffsen om at vikariere for ham. Selskabsretligt var han nemlig ikke berettiget til at nedlægge mandatet $i$ utide, men skulle sørge for en stedfortræder indtil generalforsamlingen havde valgt en afløser. Sluttelig var han ikke ganske overbevist om, at Jensen i sin egenskab af kommissær juridisk havde beføjelse til at fungere som "forretningsførende tilsynsråd " og til at opsige hans kontrakt. I hvert fald ville han forbeholde sig sine kontraktmæssige rettigheder. ${ }^{53}$

Den 24. juni var indbydelserne til generalforsamlingen blevet udsendt ledsaget af den ovenfor nævnte skrivelse fra Jensen til Flensborggruppens medlemmer, $i$ hvilken han indstændigt opfordrede alle til at møde personligt op. ${ }^{54}$ Sidst i juni indløb samtidig en række forespørgsler fra de overordnede instanser i Berlin om, hvorledes statskommissærens virksomhed udviklede sig. ${ }^{55}$ Overpræsidiets svar findes ikke blandt akterne, men kan kun have været optimistisk. Generalforsamlingen den 11. juni fik da også ganske det af regeringen ønskede forløb. Forsvundet fra Flensburger Nachrichten var herefter foruden Wacker også forretningsfører Bethke og den politiske redaktør Fritz Kammers. Ny tilsynsrådsformand blev dr. Elsner, mens Jensen blev forretningsfører og forlagsleder. Såvel den ny chefredaktør, dr. Fröbe, som den grænsepolitiske redaktør, Grunow, var gode nazister. ${ }^{56}$

Den 15. juli underrettede Jensen officielt overpræsidiet om, at hans mission var afsluttet. ${ }^{57}$ I en samme dag afsendt underhåndsskrivelse til Lohse skitserede han sine planer for avisens fremtid. Nyordningen skulle føres konsekvent igennem. Den 20. juli skulle læserne og befolkningen opfordres til aktivt medarbejde på den ny avis, og Jensen ønskede, at Lohse skulle sende bladet en kort skrivelse, som kunne åbne Flensburger Nachrichten »den neuen Weg« og give det passerede Gauleiter'ens officielle anerkendelse. Jensen ville desuden bede landråd i Flensborg landkreds, dr. Sievers, kredsleder Claus Hans og bykredsledelsen i Flensborg om et par ord til offentliggørelse, såfremt Lohse var indforstået hermed. I stedet for de hidtidige undertitler Flensburger Zeitung og Flensburger Tageblatt, ville der $\mathrm{i}$ bladhovedet fremover stå Flensburger N. S. Zeitung, hvilket han også håbede, at Lohse ville bifalde. $^{58}$

Det ville Lohse imidlertid ikke. I sit svar understregede han, at det passerede ikke betød, at Flensburger Nachrichten nu var et partiorgan. Der var tale om et privat foretagende, hvor staten tilfældigvis var indehaver af en dominerende stilling, hvilket var en helt anden sag. Desuden havde bladet en vis udbredelse $i$ udlandet - Lohse tænkte her 
sikkert på Danmark og måske de øvrige nordiske lande - hvor man ville hæfte sig ved ændringer, hvilket ikke var ønskeligt. ${ }^{59}$ Jensen måtte altså affinde sig med en mere diskret magtovertagelse, end han egentlig havde tænkt sig. I overensstemmelse hermed omtaltes ændringerne end ikke i bladet, og den ny redaktion præsenteredes ikke; et blik på Flensburger Nachrichten den 22. juli 1933 viser dog en mere udpræget nazistisk holdning end hidtil. En artikel af den ny chefredaktør Fröbe afsluttedes således med konklusionen »Hitler har altid ret«, ligesom parolen nu klart var opdragelse til en god national-socialistisk holdning. Dette var da også tydeligt nok for den danske presse, som registrerede ændringerne. Flensburger Nachrichten bagatelliserede dette den 25. juli under henvisning til, at i Tyskland var situationen nu den: »Vi er alle nazis $«{ }^{60}$ Den 25 . underrettede Lohse tillige Berlin om, at sagen nu var $i$ orden og aktionen gennemført med held. ${ }^{61}$ Nazisterne havde nået deres mål. Endnu en hidtil uafhængig - omend ikke særlig modig - avis var blevet bragt under kontrol, og Max Winkler kunne kun være tilfreds. En irriterende parantes i hans avisimperium var blevet bragt til afslutning.

\section{Konklusion}

Selv om det ikke har været muligt at dokumentere, hvem der tog initiativet til at genoptage striden om Deutscher Schutzverlags anparter i Flensburger Nachrichten i foråret 1933 - hvorved ensretningsprocessen indledtes - taler særdeles meget for, at det var Winkler, som åbenbart ikke havde svært ved at overbevise de ny magthavere om, at også de havde en interesse i at få denne sag bragt i orden. Den praktiske gennemførelse af overtagelsen af kontrollen med bladet overlod han derimod til myndighederne, den preussiske stat, som i overensstemmelse med propagandaministeriet via statens repræsentant i SlesvigHolsten, overpræsident og Gauleiter Lohse, tog sig af projektets konkrete forløb. Den fremgangsmåde, som fulgtes, var imidlertid den af Winkler foreslåede, og det var ligeledes Winkler, der leverede den ammunition, som statens kommissær, Herbert Jensen, anvendte i sine forhandlinger med Wacker og Flensborg-gruppens ledere. Formålet med kommissærens funktion var overførsel af Wackers anparter til Deutscher Schutzverlags faktiske kontrol og afholdelse af en ekstraordinær generalforsamling i Flensburger Nachrichten/Deutscher Verlag GmbH med henblik på at få godkendt denne overdragelse, ændret vedtægterne og udskiftet tilsynsrådet. Altså hvad Winkler havde 
tilstræbt, siden striden brød ud, og det mål, han havde formuleret i sit memorandum af 20 . april 1933, og som indgik ordret $i$ Jensens kommissorium.

Da myndighederne var sig bevidst, at Wackers og Flensborggruppens stilling med rigsretsdommen i ryggen juridisk var praktisk talt urørlig, måtte der følgelig andre midler til. Eftersom det hurtigt viste sig, at indsættelsen af kommissæren ikke i sig selv bibragte modparten den fornødne forhandlingsvilje, måtte Jensen satse på revisionsrapporten, som han kunne hảbe ville indeholde ting, som kunne bruges mod bladets hidtidige ledelse. Dette synes dog kun i begrænset omfang at have holdt stik. I forhandlingerne viste Wackers person sig hurtigt at blive hovedstridspunktet. Flensborg-gruppen følte sig nok tvunget til at forhandle om overdragelse af anparterne; men Wacker ville man ikke lade i stikken. Selv om Wackers fjernelse ikke var direkte næunt i Jensens kommissorium, var det åbenbart et sine gua non for myndighederne, vel ansporet af Winkler, der nu så sin chance for at gøre gengæld for de forsmædelser, som Wacker havde udsat ham for. Såvel Winkler som Jensen opfattede tydeligvis Wacker som ophavsmanden til alle vanskelighederne. Derfor ingen halve løsninger. Flensborg-gruppens kompromisvilje på alle øvrige punkter formildede ikke kommissæren. Problemet var netop ikke nazificering af avisens indhold - det var allerede mere eller mindre en kendsgerning - men den reelle kontrol med virksomheden.

Klart er det, at situationen $i$ begyndelsen af juni 1933 var gået $i$ hårdknude. Jensen indhentede derfor hos sine politiske bagmænd mandat til at skærpe holdningen over for modparten. For første gang blev trusler om »konsekvenser « for Wackers person, og om at drage tilsynsrådet til ansvar for visse punkter i revisionsberetningen fremsat. Wacker havde tydeligvis erkendt, at slaget var tabt, og havde afleveret sine anparter. C. C. Christiansen og Hermann G. Dethleffsen havde derimod endnu ikke opgivet at opnå i hvert faldt visse indrømmelser fra myndighederne. Vel havde Wacker afleveret anparterne, men formelt skulle dette godkendes af Flensborg-gruppen, og denne godkendelse håbede de at kunne sælge mod indrømmelser på andre punkter. Jensens trusler og ubøjelighed havde imidlertid den ønskede effekt, og den sluttelig til den 11. juli 1933 fastsatte generalforsamling forløb da også efter myndighedernes ønske. Flensburger Nachrichten var herefter $\mathrm{i}$ fast statslig hånd, ledet af loyale nazister såvel forretningsmæssigt som redaktionelt, og Flensborg-gruppen var - omend stadig repræsenteret $i$ tilsynsrådet - reelt sat ud af spillet. 
Karakteristisk for den anvendte fremgangsmåde var indgrebets pseudo-legale karakter, som stod i åbenlys modsætning til den behandling, som blev oppositionelle blade til del. Vel benyttede man sig af "overtalelse" og trusler; men formaliteterne blev overholdt og de nødvendige underskrifter fremskaffet. Flensborg-gruppen måtte således - uden tvivl tænderskærende - anerkende overdragelsen af Wackers anparter, ændringen af vedtægterne og tilsynsrådets udskiftning; men til indgreb i deres økonomiske rettigheder eller mod deres personer kom det ikke. Kontrollen med bladet havde de mistet, og netop det, som flensborgerne havde frygtet, og som i begyndelsen af 1920'rne havde fået dem til at indsætte den omstridte paragraf $i$ vedtægterne (der i den af bladet eftertragtede nationale stat viste sig uden betydning), var hermed sket. Winklers anparter, som det var lykkedes at neutralisere i næsten 10 år, havde været en trojansk hest.

\section{Efterskrift}

Den effektive kontrol med både forlag og avis var dog på længere sigt ikke nok for myndighederne. I 1936 købte Winkler på "Zeitungsbedarf GmbH «'s vegne familien Maass anparter af dr. Eckener, hvorefter han besad $75 \%$ af stamkapitalen. Da det ikke lykkedes at nå til enighed med Flensborg-gruppen - stadig ledet af Christiansen og Dethleffsen, idet enkelte medlemmer dog var udtrådt - om opløsning af dennes administrationsfæellesskab for anparterne, overdrog Winkler i februar 1937 med tilbagevirkende kraft fra. 1. januar $1937 \mathrm{i}$ kraft af sin majoritet selskabet Flensburger Nachrichten til et datterselskab af Zeitungsbedarf $\mathrm{GmbH}$, Nordmarkverlag $\mathrm{GmbH}$, som af samme grund blev forlagt til Flensborg. Hermed gled Flensborg-gruppen automatisk ud. Avisen tilhørte derefter staten $100 \%$. I 1939 solgtes bladet for $700.000 \mathrm{M}$ til Vera Verlagsanstalt $\mathrm{GmbH}$ (tidl. Hugenberg, grundlagt i november 1917 for at øve indflydelse på provinspressen og senere overtaget af nazisterne. ${ }^{62}$ Dette var en ren teknisk foranstaltning, som intet ændrede ved bladets status som statsejet. ${ }^{63}$

Med den tyske kapitulation i maj 1945 var Flensburger Nachrichtens æra foreløbig ude. Sidste nummer udkom den 9. maj. En kort tid levede navnet videre som titel på den britiske besættelsesmagts meddelelsesblad Flensburger Nachrichten-Blatt. I 1946 begyndte briterne imidlertid at udstede presselicenser, og blandt de genopståede blade var da også Flensburger Nachrichten, der fra 6. april 1946 udkom under navnet Flensburger Tageblatt. I 1953 indtrådte Flensborg-gruppen 
påny i Flensburger Zeitungsverlag $\mathrm{GmbH}$, som samtidig erhvervede Flensburger Nachrichten/Grenzverlag GmbH's anparter. Bladets holdning betegnedes af dets modstandere som tværpolitisk CDU, og dets linie lå $\mathrm{i}$ klar forlængelse af linien fra Weimar-tiden. Flensburger Tageblatt er nu som før Sydslesvigs største avis og har forlængst opslugt eller udkonkurreret hovedparten af den øvrige tyske presse i landsdelen.

\section{KILDER OG LITTERATUR}

\section{Forkortet Utrykt materiale}

AWA Albert Wackers arkiv, Stadtarchiv Flensburg XII, Nr. 1729, Bd. 9-14. DOP Landesarchiv Schleswig-Holstein, Akten des Oberpräsidiums, Abt. 301, Nr. 5825.

DCB Document Center Berlin, Personalakten Elsner, Grunow, Winkler, Mundhenke m.fl.

\section{Trykt materiale}

FlAvis 1869-1969 Flensborg Avis, 1869 1. oktober 1969, Flensburg 1969.

FLBysHist

Flensburg

Koszyk

Krekeler

Rosengreen

Wermuth

Winkler

FlAvis

FIN

\section{NOTER}

1. A. Hitler: Mein Kampf, 886-890. Auflage, München 1943 , s. $262 \mathrm{ff}$.

2. Koszyk, s. 354ff.

3. Rosengreen, Manus, s. 211.

4. Grænsevagten 1933, s. 288.

5. FlBysHilst II, s. 300; FlAvis 1869-1969, s. 12, 15, 117 fr. 
6. Hele dette spørgsmål om omstruktureringen af den tyske grænsepresse i Sydslesvig med særligt henblik på fusionsforhandlinger og offentlige myndigheders rolle $i$ den forbindelse vil blive gjort til genstand for en særskilt undersøgelse.

7. AWA, bd. 9, Schröder til Wacker, 5.7., 10.7. og 14.7.1922.

8. AWA, bd. 9, Wacker til Rathenau/PrMdI, 14.9.1922, og DOP, Mundhenke, Stellungnahme ..., 9.3.1933; Wermuth s. 106.

9. Krekeler s. 13-24; Wermuth s. 264ff; Koszyk s. 273.

10. Jvf. FIN 24.10.1922 og Grenzpost 24.10.1922, lederne.

11. AWA, bd. 9, 31.10.22, Deutscher Verlag til Wacker.

12. FlbysHist s. 306-07; vedr. papirleverancer findes omfattende materiale i AWA bd. 9.

13. AWA, bd. 14, Wacker, Erklärung, 23.5 .1924 + bilag: Notariatsregister Nr. 450/23, Gesellschaftervertrag Deutscher Schutzverlag; Treuhanderklärung mellem Schutzverlag og Wacker; Treuhandvertrag mellem Konkordia og Schutzverlag. Afskrifter.

14. F.eks. AWA, bd. 14, Wacker, udat. notits fra 1923 vedr. økonomisk støtte.

15. Kunstig regningsenhed skabt p.g.a. inflationen, $1 \mathrm{GM}=10 / 42$ US Dollar.

16. AWA, bd. 14, Afskrift, Notariatsregister Nr. 266/24.

17. AWA, bd. 14, Kaufvertrag, 10.5.1924.

18. Jvf. note 16.

19. AWA, bd. 10, Winkler til Eckener, 8.5.25, og Eckener til Winkler, 22.5.25.

20. AWA, bd. 10, Niederschrift ..., 5.12.1928.

21. DOP, FIN/C. C. Christiansen og H. G. Dethleffsen til Jensen, 6.6.1933.

22. Treuhanderklärung, jvf. note 13.

23. DOP, Mundhenke, Stellungsnahme ..., 9.6.1933, og Winkler, Kurze Darstellung, 20.4.1933.

24. AWA, bd. 10, Wacker, Erklärung ..., 18.1.1928.

25. Jvf. note 20.

26. AWA, bd. 10, Justizrat Löhmann til Wacker, 9.1.1929 + bilag: afskrift af dommen; Löhmann m.fl. til Wacker, 14.1.1929 + bilag: Eckener til Löhmann, 11.1.1929.

27. AWA, bd. 10, 3.7.1929, FlN/Wacker til Fa. L. P. H. Maass.

28. Jvf. DOP, Winkler, Kurze Darstellung ..., 20.4.1933, og uddrag af rigsretsdom, bilag til FIN til Jensen, 6.6.1933.

29. Dette vil kræve en nærmere undersøgelse, idet Wermuth slutter i 1933, og Koszyk ikke går specielt ind på den udlands- og grænsetyske presses skæbne efter 1933.

30. DOP, Winkler til Lohse, 10.5.1933.

31. Bilag til ovenstående.

32. DOP, Der preussische Ministerpräsident til Lohse, 12.5.1933.

33. DOP, koncepter, DOP til DPM, DOP til Polizeipräsident Flbg. og DOP til Regierungspräsident/Schleswig, Verfügung af 15.5.1933.

34. DOP, DOP til Jensen, 15.5.1933.

35. DOP, Jensen til DOP, 19.5.1933.

36. DOP, Elsner til DOP, 19.5.1933.

37. DOP, Cura Revision, Zwischenbericht, 19.5.1933.

38. DOP, koncepter, DOP til Jensen, DOP til Ministerpräsident, etc., 24.5.33.

39. DOP, Jensen til DOP, 30.5.1933.

40. DOP, Jensen til DOP, 2.6.1933.

41. DOP, FIN til Jensen + bilag: Eingabe ..., udat.

42. Samme.

43. Samme, bilag, Eingabe ... . 
44. DOP, Jensen til DOP, 7.6.1933.

45. DOP, Mundhenke til Jensen, 10.6.1933 + bilag: Stellungnahme ... .

46. DOP, "Reihenfolge der bei den FIN zu treffenden Massnahmen«, godkendt af Lohse ?.6.1933.

47. DOP, Jensen til DOP, 26.6.1933.

48. Samme.

49. Datoen fremgår af DOP, Wacker til H. Jensen, 26.6.1933.

50. DOP, Jensen til DOP, 26.6.1933.

51. Samme.

52. DOP, Jensen til Wacker, 23.6.1933.

53. DOP, Wacker til Jensen, 26.6.1933.

54. DOP, Bethke/FIN til alle anpartshavere, 24.6.1933, og Jensen til Flensborggruppens medlemmer, 24.6.1933.

55. DOP, PrMdI til DOP, 23.6.1933; Ministerpräsident til DOP, 27.6.1933; PrMdI til DOP, 30.6.1933.

56. Jvf. DOP, Jensen/FIN til DOP, 1.8.1933.

57. DOP, Jensen til DOP, 15.7.1933.

58. DOP, Jensen til Lohse, 15.7.1933.

59. DOP, Lohse til Jensen, 17.7.1933.

60. FIN 25.7.1933, artiklen »Neuer Geist« af Fröbe.

61. DOP, DOP til Ministerpräsident, 25.7.1933; DOP til PrMdFin, 25.7.1933, DOP til Rigspressechefen, 25.7.1933.

62. Jvf. Koszyk s. 184 og $392 \mathrm{ff}$.

63. Wermuth s. 123-24, note 2 . 
